2016-04-28

\title{
Determination of phosphorus in natural waters: A historical review.
}

Worsfold, P

http://hdl.handle.net/10026.1/4476

10.1016/j.aca.2016.02.047

Anal Chim Acta

All content in PEARL is protected by copyright law. Author manuscripts are made available in accordance with publisher policies. Please cite only the published version using the details provided on the item record or document. In the absence of an open licence (e.g. Creative Commons), permissions for further reuse of content should be sought from the publisher or author. 
1 Disclaimer: This is a pre-publication version. Readers are recommended to consult the full 2 published version for accuracy and citation. Published in Analytica Chimica Acta, 918, 8-20 3 (2016) doi: 10.1016/j.aca.2016.02.047.

5 Determination of phosphorus in natural waters: A historical review

7 Paul Worsfold ${ }^{1}$, Ian McKelvie ${ }^{1,2}$, Phil Monbet $^{3}$

8

$9 \quad{ }^{1}$ Biogeochemistry Research Centre, Plymouth University, Plymouth, Devon PL48AA, UK.

$10{ }^{2}$ School of Chemistry, The University of Melbourne, Victoria 3010, Australia.

$11{ }^{3}$ Pole Mer Bretagne Atlantique, 40 rue Jim Sévellec, 29200 Brest, France

15 Abstract

16 The aim of this paper is to introduce a virtual special issue that reviews the development of 17 analytical approaches to the determination of phosphorus species in natural waters. The focus 18 is on sampling and sample treatment, analytical methods and quality assurance of the data. The 19 export of phosphorus from anthropogenic activities (from diffuse and point sources) can result in 20 increased primary production and eutrophication, and potentially the seasonal development of 21 toxic algal blooms, which can significantly impact on water quality. Therefore the quantification 22 of phosphorus species in natural waters provides important baseline data for studying aquatic 23 phosphorus biogeochemistry, assessing ecosystem health and monitoring compliance with 24 legislation.

26 Keywords

27 Phosphorus, natural waters, water quality, sampling, sample treatment, analytical methods 28 
31 Phosphorus $(P)$ is an essential nutrient element that is used by all living organisms for growth 32 and energy transport [1] and is often the limiting nutrient for primary production in terrestrial and 33 aquatic ecosystems [2-4]. The terrestrial environment is a major $\mathrm{P}$ reservoir, with $8.4 \times 10^{8}-$ $3440 \times 10^{8} \mathrm{Tg}$ in sediments, 96,000 - 200,000 Tg in soils (<60 cm deep) and 2,600 -3,000 Tg in 35 terrestrial biota [5]. In the aquatic environment the major reservoirs are the surface $(0-300 \mathrm{~m})$ 36 ocean $(2,700 \mathrm{Tg})$, the deep $(300-3,000 \mathrm{~m})$ ocean $(87,000 \mathrm{Tg})$ and oceanic biota $(50-140$ $37 \mathrm{Tg})$. The atmospheric environment is a relatively small reservoir $(0.03 \mathrm{Tg})$ [5] but can be an 38 important source for oligotrophic ecosystems [6]. The major $\mathrm{P}$ fluxes are between marine biota 39 and ocean water, between soil biota and soil, from soil to the surface ocean and erosion / 40 weathering of rocks. A schematic diagram of the aquatic phosphorus cycle, showing the major 41 reservoirs and fluxes, is shown in Fig. 1.

43 The intensification of agriculture has resulted in a global demand for $P$ of about $22 \mathrm{Tg}^{-1}$ from 44 mined fossil phosphate resources [7], with minable reserves estimated at 10,000-20,000 Tg 45 [5]. Current agricultural practices give rise to significant impacts on water quality due to $\mathrm{P}$ losses 46 to water bodies, e.g. from agricultural run-off [8], e.g. elevated levels of $P$ can lead to 47 eutrophication [3, 9], harmful algal blooms, oxygen depletion and mortality of biota. Population 48 growth and increasing industrialisation are also drivers of elevated $\mathrm{P}$ inputs to natural waters 49 [10] from both diffuse and point (e.g. sewage treatment works) sources [11]. This has led to 50 "cultural eutrophication", which is the accelerated anthropogenic enrichment of the environment 51 with nutrients and the concomitant production of undesirable effects [12].

53 Dissolved inorganic $\mathrm{P}$ (DIP), in the form of orthophosphate, is easily utilized by primary 54 producers and is therefore the major bioavailable form of $\mathrm{P}$, but some dissolved organic $\mathrm{P}$ 55 (DOP) species can also be utilized $[13,14]$. The fractionation and speciation of phosphorus are 
56 therefore important factors when considering the impact of the element on water quality. In

57 natural waters phosphorus can be found in various "dissolved" forms (operationally defined as

58 the fraction that passes through a 0.2 or $0.45 \mu \mathrm{m}$ filter [15]), mostly as inorganic

59 orthophosphates and condensed or polyphosphates, but also as organic phosphates (e.g.

60 nucleic acids, proteins, phospholipids, phosphoamides, sugar phosphates, inositol phosphates,

61 aminophosphonates and organic phosphorus pesticides). "Particulate" $\mathrm{P}$ (defined as the fraction

62 retained on a 0.2 or $0.45 \mu \mathrm{m}$ filter [15]) can include clay and silt-associated organic and

63 inorganic $\mathrm{P}$, precipitates of authigenic origin and $\mathrm{P}$-containing biological matter. Colloidal

64 phosphorus is commonly referred to as the $P$ fraction in the $1 \mathrm{~nm}-1 \mu \mathrm{m}$ size range [16-18] and

65 hence both the operationally defined dissolved and particulate fractions can contain colloidal P.

66 This fraction includes both organic and inorganic species of biological and/or mineral origin. The

67 various operationally defined $\mathrm{P}$ fractions in natural waters, based on filtration and/or digestion,

68 are shown in Fig. 2, together with examples of the types of phosphorus species found in these 69 fractions.

71 The ultimate analytical challenge is therefore to develop reliable analytical methods that are 72 sufficiently sensitive and accurate to determine the concentrations of individual phosphorus 73 species in each of these fractions. Given the spatially and temporally dynamic nature of $P$ 74 transport, both frequent and widespread measurements are also desirable. For reliable 75 measurements robust sampling strategies are also required [19]. In the longer term remote 76 monitoring networks may overcome the need for sampling [20] but in situ sample treatment 77 remains a challenge.

79 For water quality management purposes it is also informative to determine the loads [21, 22] 80 and fluxes [23] of $\mathrm{P}$ species in water bodies in order to investigate, e.g. internal cycling 81 processes [24], the restoration of eutrophic ecosystems [25] and the impacts of $P$ runoff from 82 land on the ecological status of receiving waters [26]. Long-term datasets ( $\geq 20$ years), which 
83 require routine monitoring, are useful for identifying non-hydrological variations in $P$

84 concentrations and distributions, to contextualise contemporary datasets [27-29] and help to 85 validate catchment models [30].

87 The potentially adverse impact of elevated phosphorus concentrations in natural waters has led

88 to the inclusion of phosphorus standards in various national and international legislative 89 frameworks and guidelines. In Europe the Water Framework Directive (WFD - 2000/60/EC) [31] 90 covers river basins, estuaries and coastal margins and the Marine Strategy Framework 91 Directive (MSFD, 2008/56/EC) covers marine waters [32]. In the UK the specific legislation 92 relating to phosphorus is discussed in reports by the UK Technical Advisory Group on the Water 93 Framework Directive (UKTAG) [33, 34]. Revised standards proposed in the 2013 report [34] 94 build on "improvements in understanding of the relationship between phosphorus 95 concentrations and the response of river plant communities" and were derived from "a new 96 approach to setting phosphorus standards that produces site-specific estimates of natural 97 phosphorus concentrations, taking account of a site's alkalinity and altitude". The key driver for 98 emerging legislative $\mathrm{P}$ concentrations for defining river water quality (high, good, moderate, 99 poor or bad) is therefore a closer linkage with local biological responses. Reliable 100 measurements of phosphorus species in natural waters, as discussed above, will be a 101 prerequisite for further refinement of legislative guidelines for $P$.

2. Sampling and sample treatment

\subsection{Sample collection}

107 Prior to sample collection it is important to ensure that the sampling strategy is fit for purpose 108 [19]. This includes the identification of appropriate sampling locations (with due regard to 109 access and safety issues), the frequency of sample collection and the $P$ species to be 
determined. This requires a clear statement of the objectives of the sampling programme and 111 an understanding of $\mathrm{P}$ biogeochemistry and the stability of the $\mathrm{P}$ determinands [35]. The figures 112 of merit of the intended analytical methods should also be specified, e.g. detection limit, linear 113 range, selectivity, accuracy and precision, together with any constraints on time and cost, in 114 order to select the most appropriate sample collection and detection strategies [36]. Samples 115 can be collected manually (discrete grab samples or integrated cross-sectional samples) or by 116 deploying an automatic sampler for time series acquisition [37]. In the latter case, appropriate 117 quality assurance is necessary to allow for the fact that different samples will be stored 118 unfiltered for different lengths of time [38]. Replicate sampling at each location/time is strongly 119 recommended and in situations where only one sample can be collected, at least three sub120 samples should be analysed for robust quantification [39].

122 The sampling strategy should take account of temporal and spatial variability in $\mathrm{P}$ 123 concentrations and ensure that collected samples are representative of the water body being 124 sampled. Spatial variability is influenced by point and diffuse inputs, in-water processes (e.g. 125 plant, algal and bacterial turnover), mixing zones, thermal stratification with depth in lakes or 126 salinity stratification in estuaries. Temporal variability is influenced by seasonal (e.g. summer 127 base flow compared with higher autumn and winter flows) and short-term (e.g. rain events) 128 changes in river flow [40] and physico-chemical gradients (e.g. temperature and salinity) [41].

130 Clean sample containers and sample collection apparatus (including filters) are an essential 131 prerequisite for minimising contamination and most cleaning methods involve acid washing, e.g. 132 soaking items overnight in a nutrient free detergent, rinsing with ultra-pure water, followed by 133 soaking overnight in $10 \% \mathrm{HCl}$, and finally rinsing with ultra-pure water [42]. 134 Polytetrafluoroethylene (PTFE) or high density polyethylene (HDPE) are the preferred materials 135 for containers but quartz, borosilicate glass, low density polyethylene and polypropylene have 
136 also been used. The analytical requirements of the detection method will dictate the minimum

137 sample volume. Use of containers with a larger size [43] and lower surface area to volume ratio 138 [44] should minimise adsorptive losses. Cleaned sample containers should be rinsed three 139 times with the sample prior to filling. When collecting samples it is good practice to utilise 140 sample blanks to monitor the sampling process.

2.2 Sample pretreatment and storage

144 After the collection of representative water samples it is essential that they are effectively 145 treated and stored in order to maintain sample integrity. Filtration is the most common form of 146 sample pretreatment to separate the dissolved and particulate phases, as defined above. This 147 step should ideally be carried out at the time of sample collection to prevent changes in $\mathrm{P}$ 148 fractionation and speciation. Polycarbonate (e.g. Nuclepore ${ }^{\circledR}$ ), cellulose acetate or cellulose 149 acetate/nitrate $47 \mathrm{~mm}$ diameter membrane filters are commonly used but larger diameter and 150 capsule filters have also been reported [45]. A $0.45 \mu \mathrm{m}$ filter provides faster filtration than a 0.2 $151 \mu \mathrm{m}$ filter but the latter has the advantage of removing the majority of bacteria, picoplankton and 152 colloidal species that could impact on dissolved $P$ concentrations during storage $[35,46,47]$.

153 Filtration can be carried out under vacuum or positive pressure but an excessive pressure 154 gradient across the membrane can rupture algal cells, releasing intracellular contents into the 155 sample, and/or disaggregate colloidal material. Highly turbid samples can lead to rapid clogging 156 of the filter, particularly with smaller nominal pore size filters.

158 The characteristics of selected storage/preservation methods for the determination of 159 phosphorus are summarised elsewhere [42, 44]. A variety of physical (e.g. refrigeration, 160 freezing $\left(-4^{\circ} \mathrm{C}\right)$, deep-freezing $\left(-20^{\circ} \mathrm{C}\right)$ ) and chemical (e.g. addition of chloroform, mercuric 161 chloride) preservation techniques have been used to maintain the original phosphorus 
concentration and speciation during storage but there is not a generic treatment protocol that is 163 ideal for all environmental situations. Factors such as phosphorus concentration, water 164 hardness, salinity, dissolved organic matter, particulate matter and biological conditions need to 165 be considered. For example, in lowland chalk catchments freezing samples can lead to 166 phosphate being co-precipitated with calcite when samples are thawed [42, 48,49] and for such 167 samples storage at $4{ }^{\circ} \mathrm{C}$, with chloroform addition to prevent biological growth, was 168 recommended [42].

2.3 Sample digestion

172 For the determination of total phosphorus (TP; unfiltered samples) and total dissolved 173 phosphorus (TDP; filtered samples) it is necessary to convert all of the phosphorus-containing 174 species into a detectable form. For natural waters the most common method of detection is the 175 "molybdenum blue" chemistry with spectrophotometric detection which determines molybdate176 reactive orthophosphate $\left(\mathrm{PO}_{4}^{3-}\right)$ using either a batch or flow-based approach (see §3.1) [50].

177 Inductively coupled plasma based methods (ICP-AES and ICP-MS) can also be used if the 178 concentration of $\mathrm{P}$ is sufficiently high. The process of conversion, which involves the breaking of 179 P-O-P, C-O-P and C-P bonds in condensed and organic $\mathrm{P}$ compounds is called digestion and is 180 typically achieved by thermal oxidation with hydrolysis using either an autoclave, digestion block 181 or microwave [51] or by UV photo-oxidation with or without heating.

183 Autoclaving is generally simple and quick, gives reproducible results and is carried out in sealed 184 vessels to minimise contamination $[44,47]$. Peroxydisulfate is the preferred oxidant and was 185 first used for the determination of TP in seawater in the 1960s [52]. Since then a variety of 186 peroxydisulfate methods, in either acidic [53] or basic [54] media, have been reported [47]. 187 Autoclaving with alkaline peroxydisulfate, rather than acidic peroxydisulfate, is recommended 
188 for the simultaneous determination of TP and total nitrogen (TN) and for the digestion of marine 189 waters due to the oxidation of chloride to free chlorine by peroxydisulfate in acidic media, which 190 reduces its oxidising power [55]. When alkaline peroxydisulfate digestion is used, autoclaving or 191 thermal heating should be continued until $\mathrm{S}_{2} \mathrm{O}_{8}{ }^{2-}$ is converted to hydrogen sulphate $\left(\mathrm{HSO}_{4}{ }^{-}\right.$; pKa $192=1.99)$ so that a low $\mathrm{pH}$ is reached in the latter stages of the digestion and acid hydrolysis of 193 condensed phosphate species is achieved [51]. An acidic peroxydisulfate method was reported 194 by Gales et al. [56] and simplified by Eisenreich et al. [57]. The method gives good recoveries 195 and is simple and easy to use and is therefore recommended for the determination of TP and 196 TDP in fresh waters [58].

198 UV photo-oxidation can be used for the digestion of marine and freshwaters [41,59] but if the 199 sample contains condensed polyphosphates, heating with $\mathrm{HCl}$ or peroxydisulfate after UV 200 irradiation is recommended [60]. UV photo-oxidation also gives good recoveries when 201 incorporated into a flow injection (FI) manifold [61, 62]. Microwave digestion has also been used 202 in flow systems in conjunction with spectrophotometric detection [51, 63] and ICP-MS detection $203[64]$.

205 The above methods provide a quantitative measurement of TP or TDP but if information on 206 specific classes of $\mathrm{P}$ compounds is required, a more selective method of sample treatment is 207 necessary, e.g. the use of phosphate cleaving enzymes such as acid and alkaline 208 phosphatases, and this is discussed in § 3.3.

3. Analytical methods

\subsection{Dissolved reactive phosphorus}


214 Most methods for phosphorus determination are based on the spectrophotometric detection of 215 the intensely coloured phosphomolybdenum blue (PMB). This complex is formed by reaction of 216 phosphate with acidified molybdate producing 12-molybdophosphosphoric acid (12-MPA), 217 which is subsequently reduced to phosphomolybdenum blue [65], i.e.

$219 \mathrm{PO}_{4}{ }^{3-}+12 \mathrm{MoO}_{4}{ }^{2-}+27 \mathrm{H}^{+} \rightarrow \mathrm{H}_{3} \mathrm{PO}_{4}\left(\mathrm{MoO}_{3}\right)_{12}+12 \mathrm{H}_{2} \mathrm{O}$

$\mathrm{H}_{3} \mathrm{PMo}(\mathrm{VI})_{12} \mathrm{O}_{40}+$ Reductant $\rightarrow\left[\mathrm{H}_{4} \mathrm{Mo}(\mathrm{VI})_{8} \mathrm{Mo}(\mathrm{V})_{8} \mathrm{O}_{40}\right]^{3-} \quad$ (Phosphomolybdenum blue)

"Molybdate reactive" phosphorus (MRP) in the dissolved fraction is variously described as dissolved reactive phosphorus (DRP), soluble reactive phosphorus (SRP) and filterable reactive phosphorus (FRP) in recognition that this fraction may also include some acid labile, molybdatereactive organic and condensed and colloid-associated phosphorus species. This can lead to overestimation of free phosphate [65]. While some have suggested that ion chromatography gives a better estimate of free orthophosphate [66] than DRP, Hens and Merx used gel filtration to demonstrate that in $0.45 \mu \mathrm{m}$ filtered soil solution, both MRP and ion chromatographic $\mathrm{P}$ measurements overestimated the free orthophosphate concentration by up to 2.3- and 1.4-fold, respectively [67]. Despite this, DRP is still the most widely used surrogate measure of readily bioavailable $\mathrm{P}$ because it is practically convenient to measure.

234 A variety of reductants (e.g. ascorbic acid, tin(II) chloride, hydrazine sulfate, hydroquinone) and acids have been used in this reaction [50], giving rise to a range of PMB species with different absorbance spectra. Appropriate acid and molybdate concentrations are critical for the 237 formation of PMB; for example, in low acidity conditions, non-linear colour development and 238 self-reduction of the molybdate can occur [68]. The chemistry of phosphomolybdenum blue 239 formation has been comprehensively reviewed by Nagul et al. [50]. 
241 The most cited and widely used method is that reported by Murphy and Riley [69] in 1962 which 242 utilised ascorbic acid in the presence of $\mathrm{Sb}$ (III) as the reductant. When $\mathrm{Sb}$ (III) is present, the 243 rate of formation of molybdenum blue is enhanced compared with ascorbic acid alone (although $244 \mathrm{Sb}$ does not act as a catalyst, as is often claimed), and $\mathrm{Sb}$ is incorporated into the complex as $245\left[\mathrm{PSb}_{2} \mathrm{Mo}_{12} \mathrm{O}_{40}\right]^{-}$which has a $\lambda_{\max }$ at $880 \mathrm{~nm}$. The optimum conditions for the formation of the 246 molybdenum blue complex was further investigated by Going and Eisenreich [70]. This reaction 247 is less sensitive to salt than others, and colour development is fairly independent of temperature 248 [71], making it the preferred reaction for the determination of phosphorus in natural waters.

Tin(II) chloride has also been used as a reductant, especially for the determination of phosphate in freshwaters, because the reaction is rapid and the absorptivity is greater than that for ascorbic acid/Sb(III). In the reduction process, $\mathrm{Sn}(\mathrm{IV})$ is substituted for $\mathrm{Mo}(\mathrm{VI})$ in the $\mathrm{PMB}$ complex, to form $\alpha-\left[\mathrm{Pmo}_{10} \mathrm{Sn}_{2} \mathrm{O}_{37}\right]^{5-}$, shifting $\lambda_{\max }$ to $700 \mathrm{~nm}$ and enhancing the absorptivity. At 254 this wavelength, absorbance can be measured using simple solid state detectors that utilise red light emitting diodes as the light source $[72,73]$, and this approach has been widely adopted for flow analysis systems intended for field application [74]. However, chloride inhibits the reduction 257 process by complexing with $\mathrm{Sn}(\mathrm{IV})$, and a decrease in sensitivity of ca. $15 \%$ occurs in a 258 seawater matrix compared with that of deionized water [75]. Despite this limitation, reduction with tin(II) chloride has been favoured for automatic flow analysis of non-saline waters because of the faster reaction kinetics and higher sensitivity.

262 In addition to the homogeneous reduction methods described above, an on-line UV photo263 reduction method has recently been reported [76]. In this system molybdophosphate was 264 reduced to phosphomolybdenum blue in the presence of a hydrogen bond donor (ethanol), using a simple Teflon $^{\circledR}$ tube UV reactor in a FI system. Because the PMB produced by UV 266 photo-reduction is transient, the reaction is best performed under the highly controllable and 
reproducible conditions achieved using a flow system. Unstable chemical reducing reagents 268 such as ascorbic acid or tin(II) chloride are not required, making this approach more suitable for 269 longer term field based measurements.

271 Species that can interfere with the formation of the PMB complex include silicate, arsenate, 272 nitrite, nitrate, sulphide, chromium and copper [50, 77]. Silicate interference can be minimised 273 by careful adjustment of the acid and molybdate concentrations [71], and by the inclusion of 274 tartrate in the reagent mixture [78]. Interferences from arsenate can be eliminated by reduction 275 of $\mathrm{As}(\mathrm{V})$ to $\mathrm{As}(\mathrm{III})$ by the addition of sodium thiosulfate $[71,79]$.

277 Flow analysis techniques can be advantageous in treating or avoiding interferences in the 278 determination of DRP. For example, Grace et al. described a FI method for DRP measurement 279 in anoxic estuarine sediment pore waters, using on-line pre-oxidation of sulphide with 280 permanganate prior to spectrophotometric detection [80], in which the selectivity was not 281 compromised by the oxidation of organic $\mathrm{P}$ species commonly found in this matrix. Additionally, 282 the use of $\mathrm{Fl}$ enabled the analysis to be performed without exposure of samples to the 283 atmosphere, thus avoiding changes in the redox condition.

An early (1982) application of FI to DRP measurement in marine systems involved the use of reagent injection or "reverse" FI analysis [81]. In this approach, a defined volume of a combined colorimetric reagent, containing ascorbic acid and antimonyl tartrate as the reductant, was 288 injected into a flowing stream of sample with heating to $50{ }^{\circ} \mathrm{C}$. This approach resulted in 289 arguably higher sensitivity, more economical reagent use and a better suitability for on-line or 290 under way monitoring applications than conventional FI. A similar multiple reagent injection 291 approach (multi-commutation) was described by Lyddy-Meaney et al. [74] for DRP 292 determination in a portable $\mathrm{FI}$ system, using tin(II) chloride reduction at ambient temperature. 293 This system included on-line $0.2 \mu \mathrm{m}$ tangential-flow filtration and a specially designed multi- 
294 reflection optical flow cell that minimised Schlieren effects caused by variations in the refractive 295 index of estuarine and marine waters [82]. The system was used for chemical mapping and 296 spatial resolution of one measurement per $250 \mathrm{~m}$ was achieved at an injection rate $225 \mathrm{~h}^{-1}$ and 297 a boat speed of 30 knots (Fig. 3).

Non-spectrophotometric detection methods involving the formation of molybdophosphoric acid have also been investigated for the determination of phosphate, e.g. amperometric detection of phosphate as molybdophosphate [83-86]. Determination of phosphate based on the fluorescence quenching of the molybdate ion association complex with fluorophores such as rhodamine $\mathrm{B}$, rhodamine $6 \mathrm{G}$ or thiamine by phosphate is reportedly more sensitive than spectrophotometric methods based on phosphomolybdenum blue [87, 88]. For example, Frank et al. [89] demonstrated a sequential injection analysis system for DRP determination using the fluorescence quenching of rhodamine $6 \mathrm{G}$-molybdate to achieve a LOD of $0.05 \mu \mathrm{M}$ at a high sample throughput of $270 \mathrm{~h}^{-1}$. This system was used effectively for surface water transect measurements in the North Sea, Wadden Sea and Elbe estuary. More recently, Kröckel et al. reported a reverse $\mathrm{FI}$ method using the same chemistry that achieved a LOD of $7 \mathrm{nM}$ for phosphate measurements in seawater [90]. A FI method with chemiluminescence detection based on luminol oxidation by 12-MPA has also been used to determine phosphate in 312 freshwaters [91].

314 The LOD of batch spectrophotometric phosphomolybdenum blue methods is typically in the low $315 \mu \mathrm{g} \mathrm{P} \mathrm{L}{ }^{-1}$ range, e.g. the APHA standard methods publication quotes a LOD of about $3 \mu \mathrm{g} \mathrm{P} \mathrm{L}^{-1}$ 316 with tin(II) chloride reduction $(0.1 \mu \mathrm{M})$ and $10 \mu \mathrm{g} \mathrm{P} \mathrm{L}^{-1}$ with ascorbic acid reduction (0.3 $\left.\mu \mathrm{M}\right)$ [92]. 317 These LODs are inadequate for the determination of DRP in low nutrient (oligotrophic) waters. A 318 number of approaches have therefore been described to enhance the sensitivity of spectrophotometric PMB methods, viz; by modification of the chromophore detected, e.g. by ion pairing of molybdophosphate with a dye, preconcentration by extraction (both liquid and solid 
phase), ion exchange or coprecipitation, or the use of spectrophotometric cells with an extended optical path length.

324 As an alternative to the direct measurement of PMB, some authors have used the formation of 325 ion association complexes between basic dyes and molybdophosphoric or vanadatemolybdophosphoric acid as the basis for DRP determination, with sensitivity arguably better 327 than the PMB method [93]. However, a surfactant must be used to avoid precipitation of the ion328 association complex, and this can be a major source of blank contamination [79].

330 Solvent extraction can be performed to enhance sensitivity, either by extracting molybdophosphate followed by reduction, e.g. with tin(II) chloride [92], or by extracting after the 332 formation of PMB as described by Strickland and Parsons [94]. Solvents used include iso333 propanol, n/iso-butanol, n/iso-butanol + benzene, n-hexanol and butyl acetate [95]. Detection 334 limits at the sub- $\mu \mathrm{g} \mathrm{L}^{-1}$ level were achieved for river water measurements by Motomizu and 335 Oshima, who performed solvent extraction on the ion-association pair formed between molybdophosphoric acid and Malachite Green, without reduction [96].

338 Flow-based systems readily facilitate the automation of solid phase extraction methods, 339 minimizing the use of solvent. For example, Liang et al. have reported an example of a solid 340 phase extraction $\mathrm{FI}$ preconcentration technique that is suitable for detection of DRP in marine 341 waters. This involved solid phase extraction of the phosphomolybdenum blue - cetyl 342 trimethylammonium bromide ion pair on a $\mathrm{C}_{18}$ column followed by elution with ethanol and 343 sulfuric acid before spectrophotometric detection, giving a detection limit of $1.6 \mathrm{nM}$ but with a 344 sample throughput of only $2 \mathrm{~h}^{-1}$ [95]. In a related approach, Nagul et al. used polymer inclusion 345 membranes (PIMs) in combination with a FI manifold to perform on-line extraction of phosphate 346 directly from low ionic strength fresh waters before stripping and detection as PMB. A detection 347 limit of $0.04 \mu \mathrm{g} \mathrm{L}^{-1}$ at a sampling rate of $5 \mathrm{~h}^{-1}$ was reported [97]. 
349 Ion exchange techniques in concert with flow analysis have also been described for 350 preconcentration of phosphate in freshwaters. Freeman et al. [78] used a strong anion 351 exchange resin (AG $1 \mathrm{X}-8)$ in an $\mathrm{FI}$ manifold to preconcentrate as much as $3.2 \mathrm{~mL}$ of sample. 352 Phosphate and silicate peaks were resolved when the column was eluted with $0.1 \mathrm{M} \mathrm{KCl}$, and 353 an LOD of $0.1 \mu \mathrm{g} \mathrm{P} \mathrm{L-1} \mathrm{was} \mathrm{achieved} \mathrm{with} \mathrm{a} \mathrm{sample} \mathrm{throughput} \mathrm{of} 6 \mathrm{~h}^{-1}$. Effective pre354 concentration was achieved for samples containing less than $200 \mathrm{mg} \mathrm{L}^{-1}$ chloride, making the 355 method suitable for most freshwaters. Udnan et al. reported a similar FI approach for the 356 determination of DRP that used amperometric detection of phosphomolybdate after in-valve 357 anion exchange preconcentration. A LOD of $0.18 \mu \mathrm{g} \mathrm{L} \mathrm{L}^{-1}(6 \mathrm{nM})$ was achieved using a 2 min 358 column loading time, but the method was limited to pristine freshwaters because the 359 preconcentration was adversely affected at chloride concentrations $\geq 50 \mathrm{mg} \mathrm{L}^{-1}$ [98].

The MAGIC (MAGnesium Induced Coprecipitation) method proposed by Karl and Tien [99] has been utilized by chemical oceanographers for the determination of DRP in low-nutrient ocean waters. It involves the coprecipitation of phosphate when magnesium hydroxide (brucite) is precipitated by the addition of $\mathrm{NaOH}$. Then, after separation by centrifugation, the precipitate is dissolved in $0.1 \mathrm{M} \mathrm{HCl}$ and the phosphate concentration determined as PMB. A modified method reported by Rimmelin and Moutin [100] gave a typical preconcentration factor of 25 and resulted in a detection limit of a $0.8 \mathrm{nM}$.

Enhancement of detection sensitivity can be achieved by the use of cuvettes with longer optical path lengths. In batch techniques using conventional spectrophotometers, the maximum cuvette length used was conventionally $100 \mathrm{~mm}$. However, Ormaza-González and Statham described the use of a $600 \mathrm{~mm}$ long capillary cell with a red LED light source and phototransistor detector for the detection of PMB at low $\mathrm{nM}$ concentrations [101]. The development of low refractive 374 index polymers such as Teflon ${ }^{\circledR}$ AF2400 has enabled the construction of liquid core waveguide 
375 (LCW) cells that offer the possibility of even longer optical path lengths, and these can be 376 readily configured as flow cells for use in flow analysis. For example, Gimbert et al. [102] 377 evaluated the suitability of a $1000 \mathrm{~mm}$ LCW cell for detection of phosphate as tin(II)-reduced $378 \mathrm{PMB}$ at $710 \mathrm{~nm}$ using a FI manifold, and achieved a LOD of $10 \mathrm{nM}$ (Fig. 4). Optimal results were obtained using an injection volume of $500 \mu \mathrm{L}$ (twice the internal volume of the LCW cell) and background correction at $470 \mathrm{~nm}$. Similarly Zhang et al. used a $2000 \mathrm{~mm}$ LCW cell in a segmented continuous flow system, with an LOD of $1.5 \mathrm{nM}$ [103], for underway analysis of more than 1000 samples from the west Florida continental shelf and the oligotrophic Sargasso Sea [104]. As a generality, background correction or other compensation strategies should be used to avoid Schlieren effects in these LCW cells [73].

Passive sampling techniques such as Diffusive Gradient in Thin films (DGT) can be used for the 387 in situ preconcentration of DRP [105-108]. Mohr et al. determined both DRP and low molecular 388 weight organic $\mathrm{P}$ species such as adenosine monophosphate (AMP) and myo-inositol hexakisphosphate (IP6) using DGT with an iron oxide based binding gel [107]. Monbet et al. deployed both DGT and Diffusive Equilibrium in Thin films (DET) in situ to obtain high spatial resolution ( $\mathrm{mm}$ scale) DRP sediment porewater profiles in two lagoons of the Gippsland Lakes (SE Australia). DRP concentrations were determined using the PMB method with tin(II) chloride in an automatic FI manifold [82] and the detection limit was $0.2 \mu \mathrm{g} \mathrm{P} \mathrm{L}^{-1}(0.006 \mu \mathrm{M})$.

3.2 Total and total dissolved phosphorus

397 The determination of TP or TDP requires that the sample must first be digested to convert all P 398 forms to detectable orthophosphate, as described in $\S 2.3$, before detection, usually as PMB. 399 Proposed methods should be thoroughly validated using model phosphorus compounds that range in stability from labile to refractory [109], certified reference materials and comparison with a reference method. Inductively coupled plasma - optical emission spectroscopy (ICP- 
OES) can also be used for detection if concentrations are sufficiently high. For example, Van

Moorleghem et al. reported detection limits of $6 \mu \mathrm{g} \mathrm{P} \mathrm{L}{ }^{-1}(0.2 \mu \mathrm{M})$, at $213.617 \mathrm{~nm}$ and $34 \mu \mathrm{g} \mathrm{P} \mathrm{L}^{-}$ $404{ }^{1}(1.1 \mu \mathrm{M})$, at $178.221 \mathrm{~nm}[110]$.

A number of automatic methods, based mainly on flow analysis, have been described for the determination of TP and/or TDP. For example, Ayoagi et al. [111] used a $10 \mathrm{~m}$ long capillary digestor containing a Pt wire as catalyst in an FI system to perform thermal digestion with peroxydisulfate at $160{ }^{\circ} \mathrm{C}$. Orthophosphate produced by digestion was detected using the Malachite green-molybdophosphate chemistry and a sample throughput of ca. $10 \mathrm{~h}^{-1}$ was

An alternative approach to direct heating was employed by Hinkamp and Schwedt who used a $7.6 \mathrm{~m} \mathrm{Teflon}{ }^{\circledR}$ digestion coil in a microwave oven for digestion of organic and condensed phosphates. Amperometric detection was performed in $\mathrm{Fl}$ mode, with a limit of determination of $0.1 \mathrm{mg} \mathrm{P} \mathrm{L}^{-1}$, a precision of $3 \% \mathrm{RSD}$ at $5 \mathrm{mg} \mathrm{P} \mathrm{L}^{-1}$ and a sample throughput of $20 \mathrm{~h}^{-1}$ [112]. Benson et al. described the application of a flow analysis system in which digestion was performed continuously off-line in a $6 \mathrm{~m}$ Teflon ${ }^{\circledR}$ reactor. Digestate was passed through a 419 microporous debubbler to remove gas bubbles prior to injection into a spectrophotometric FI system for detection of the PMB formed [63]. As an alternative to the use of continuous coil digestors, Almeida et al. [113] described the use of a micro-batch reactor for microwave TP digestion which was coupled with a multi-syringe $\mathrm{Fl}$ analysis system.

424 Other automatic flow systems have used UV photo-oxidation either alone [114-116] or in 425 combination with thermal digestion [115] for the determination of TP and TDP. However, while these methods were suitable for waste waters and freshwaters, Peat et al. found that for 427 samples such as soil waters, acidic photo-oxidation was required to avoid interference from the 428 higher concentrations of $\mathrm{Fe}$ and $\mathrm{Al}$ found in the matrix that complexed with phosphate [114]. 
429 Aminot and Kerouel [59] reported similar matrix problems in natural seawater using a 430 segmented continuous flow system, presumably due to complexation with $\mathrm{Ca}$ and $\mathrm{Mg}$ ions, and 431 suggested that sample dilution by a factor of $5-6$ was required to obtain complete digestion. 432 Gentle et al. found that the problem of incomplete digestion in seawater could be overcome 433 across the full salinity range $(0-35)$ in a $\mathrm{Fl}$ system if photo-oxidation combined with thermal 434 digestion when acidic peroxydisulfate was adopted. This FI system was capable of 115 435 measurements per hour, with a LOD of $1 \mu \mathrm{g} \mathrm{P} \mathrm{L}^{-1}(0.03 \mu \mathrm{M})$, and used to perform 2499 436 underway TP measurements during a cruise in the coastal waters of Victoria, SE Australia 437 [117].

\subsection{Phosphorus speciation}

441 The chemical species or forms of aquatic phosphorus can be determined using either 442 operational or functional approaches. In the former, species are defined by the chemical 443 operation involved, e.g. by the formation of PMB to give "molybdate reactive P" (cf. § 3.1), 444 whereas in the latter, highly specific assays may be applied to quantify species with particular 445 functionality, e.g. by specific enzymatic assays or chromatographic separation. The distinction 446 between operational and functional measurement is illustrated by Baldwin [118] who compared 447 spectrophotometric PMB (operationally defined) and ion chromatographic (functionally defined) 448 methods to show that only a small fraction of the filterable MRP present in eutrophic waters was 449 comprised of dissolved orthophosphate. The difference was ascribed to the hydrolysis of labile 450 organic $\mathrm{P}$ or desorption from colloidal material [118] which occurred as an artefact of the PMB 451 method.

453 The organic $\mathrm{P}$ fraction, which comprises nucleic acids, phosphoproteins and amino phosphoric 454 acids, phospholipids, inositol phosphates, phosphonates and organic condensed $\mathrm{P}$ compounds, 455 such as adenosine triphosphate, can be at least as abundant as inorganic $\mathrm{P}$ in some natural 
waters $[119,120]$. There is compelling evidence that in the absence of orthophosphate, some 457 algae and cyanobacteria can utilize phosphorus from organic $P$ compounds via enzymatic 458 hydrolysis [5, 70, 121-127]. Consequently there is growing interest in methods for the 459 determination of organic $P$ [128], which hitherto was considered unavailable, and hence was 460 ignored as a source of bioavailable $\mathrm{P}$.

\subsubsection{Operational speciation}

464 The most common operational delineation of phosphorus species is that based on filtration to 465 discriminate between the so-called dissolved or filterable fraction and particulate forms (cf. $\S 2.2$ 466 and Fig 2). Thereafter, digestion (with strong acids/bases and oxidants (cf. § 3.2), or dilute acid 467 hydrolysis can be performed to obtain estimates of the amount of total or condensed 468 phosphorus forms present within either the filterable or particulate size fractions. The organic 469 fraction has conventionally been determined as the unreactive residual fraction after the 470 reactive and condensed fractions have been subtracted from the total $P$ concentration $[92,129]$.

472 A convenient, operational, non-specific measure of organic $\mathrm{P}$ can be achieved using alkaline 473 UV photo-oxidation in a flow system with a low wattage lamp [59, 62, 116]. Under alkaline, rapid 474 photo-oxidation conditions, minimal hydrolysis of condensed $\mathrm{P}$ occurs, and what is detected is 475 the sum of (DOP + DRP). DOP is therefore determined by subtracting the DRP, with the caveat 476 that DRP may already include some labile DOP.

\subsubsection{Functional speciation}

480 Strickland and Solorzano [130] and Herbes et al. [131] were among the first to determine 481 alkaline phosphatase-hydrolysable phosphate in sea and lake waters as a means of measuring 482 the phosphomonoester fraction. A similar approach has been applied using a suite of different 
483 phospho-enzymes to characterise organic $\mathrm{P}$ in natural waters. Turner et al. [132] performed a 484 series of enzymatic reactions utilising alkaline phosphomonoesterase (labile monoester P), 485 phosphodiesterase + alkaline phosphomonoesterase (diester- $\mathrm{P}$ compounds) and phytase 486 (inositol hexaphosphate) to characterise organic $P$ in soil solution, and a similar approach was 487 adopted by Monbet et al. in a study of coastal lake [133] and estuarine [13] waters using the FI 488 manifold shown in Fig. 5.

490 The use of $\mathrm{FI}$ techniques with immobilised enzyme reactors enables convenient and rapid 491 measurement of these enzymatically available organic $P$ fractions. Shan et al. determined 492 alkaline phosphatase-hydrolysable phosphorus using immobilized alkaline phosphatase from $E$. 493 coli [134, 135], while similar approaches have been applied for phytase-hydrolysable 494 phosphorus with 3-phytase [136] in natural waters using FI systems. However, since the 495 detection step for all of these reactions involves the measurement of PMB, the enzymatic 496 selectivity may be compromised because some labile $\mathrm{P}$ species may also be molybdate 497 reactive. Ideally, a more selective technique such as ion chromatography could be used to 498 overcome this deficiency.

500 Arguably chromatographic separations can be included in the category of "functional" 501 techniques because the detected species are separated on the basis of their hydrophobicity or 502 charge prior to detection using a variety of techniques. Ion chromatography (IC) with 503 suppressed electrical conductivity detection is widely and routinely used for the quantification of 504 orthophosphate in fresh waters. IC has also been applied to speciation of both inorganic and 505 organic phosphorus moieties using a variety of post separation detection methods [137]. For 506 example, separation of ortho-, di- and tri-phosphate in wastewaters was described by Jolley et 507 al. using ion exchange chromatography with post column detection of PMB following autoclave 508 digestion [138]. Interestingly, Jolley et al. did not detect any condensed phosphate in 509 wastewaters. However, Halliwell et al. [139] using IC coupled to on-line post column digestion 
using a FI system, demonstrated that the half-life of triphosphate was less than $10 \mathrm{~h}$, thus 511 accounting for its apparent absence [139]. Espinosa et al. [125] used a similar ion 512 chromatographic approach, but with off-line TP digestion and detection, to study P speciation in 513 soil leachate waters.

515 Ion chromatography has also been coupled with ICP-AES for the on-line determination of 516 orthophosphate and glyphosate [140] and phosphite, hypophosphite, pyrophosphate and 517 tripolyphosphate [141]. Similarly, mass spectrometry has been coupled with IC for the 518 determination of hypophosphite, phosphite, and phosphate [142] and dialkyl phosphinate acids

519 [143] in water. These hyphenated separation-detection techniques show the greatest potential 520 for selective speciation of the plethora of organic and inorganic $P$ species that may occur in 521 natural waters (and wastewaters).

4. Quality assurance of phosphorus data

525 Phosphorus, particularly in the form of DRP, is a key determinand in many environmental 526 monitoring programmes and it follows that accurate data are required to implement water quality 527 management strategies and monitor compliance with environmental standards [47]. Total 528 phosphorus (TP) is also determined, although less frequently than DRP, and is important for 529 monitoring discharges from, e.g. wastewater treatment plants and determining P loads [29]. 530 General guidelines on data quality can be found in ISO/IEC 17025 [144] and specific discussion 531 of nutrient data quality (including $\mathrm{P}$ ) in marine waters, together with a practical illustration of how 532 to determine an uncertainty budget, is presented by Worsfold et al. [145].

534 Certified reference materials (CRMs) are an important component of any quality assurance 535 programme for the determination of dissolved phosphorus in natural waters and this was 
561 Phosphorus speciation provides an additional analytical challenge due to the need for increased 562 selectivity and, often, lower detection limits. Speciation can be defined operationally (e.g. by 563 filtration) or functionally. Functional selectivity can be achieved by the use of selective reagents 564 (e.g. enzymes) or by prior separation (e.g. using ion chromatography). Combining separation 565 strategies with powerful detection techniques such as mass spectrometry is the most promising 566 way forward for a more complete characterisation and quantification of the dissolved 567 phosphorus pool.

569 Rigorous quality assurance procedures are required in order to ensure compliance with the 570 legislative requirements for phosphorus in natural waters as well as supporting water quality 571 management strategies and biogeochemical studies. This in turn generates a need for stable, 572 matrix specific reference materials that are certified for phosphorus species at environmentally 573 relevant concentrations.

\section{Abbreviations}

12-molybdophosphoric acid

577 CRM

certified reference material

578 DET

Diffusive Equilibrium in Thin films

579 DGT

Diffusive Gradient in Thin films

580

DIP

dissolved inorganic $\mathrm{P}$

DOP

dissolved organic $\mathrm{P}$

$582 \quad$ DRP

dissolved reactive phosphorus

$583 \mathrm{FI}$

Flow injection

584 FRP

filterable reactive phosphorus

585

HDPE

high density polyethylene

586

IC

ion chromatography

58

ICP-AES

inductively coupled plasma-atomic emission spectrometry 
588 ICP-MS inductively coupled plasma-mass spectrometry

589 LCW liquid core waveguide

590 LED light emitting diode

591 LOD limit of detection

592 MAGIC MAGnesium Induced Coprecipitation

593 MRP molybdate reactive phosphorus

$594 \mathrm{P} \quad$ phosphorus

595 PMB phosphomolybdenum blue

596 PTFE polytetrafluoroethylene

597 SRP soluble reactive phosphorus

598 TDP total dissolved phosphorus

599 TP total phosphorus

600 UV ultra-violet

601

602 
Fig. 1. A schematic diagram of the aquatic phosphorus cycle. Flux and reservoir data obtained from [5, 121, 150-158].

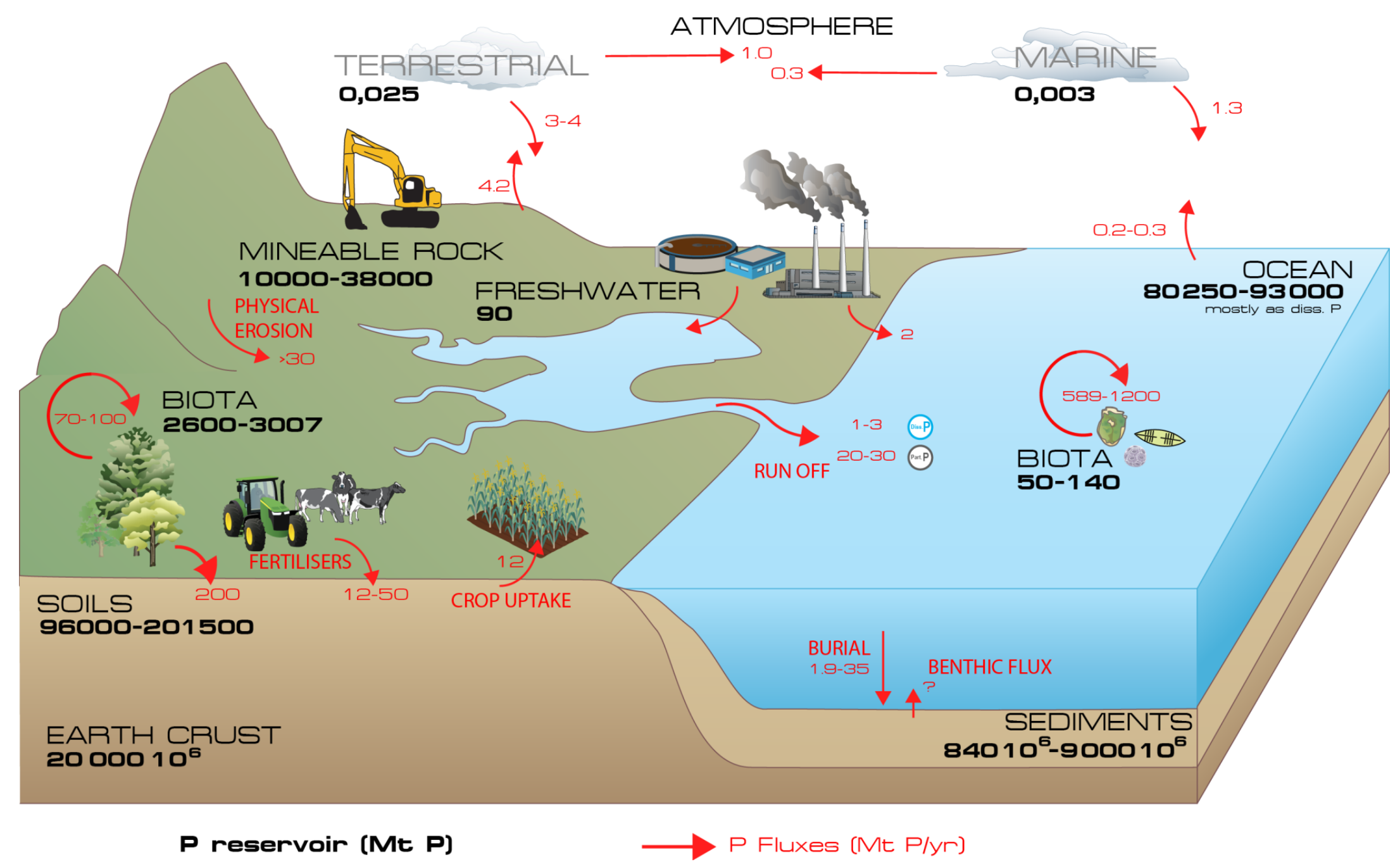


Fig. 2. The various operationally defined $P$ fractions in natural waters, based on filtration and/or digestion.

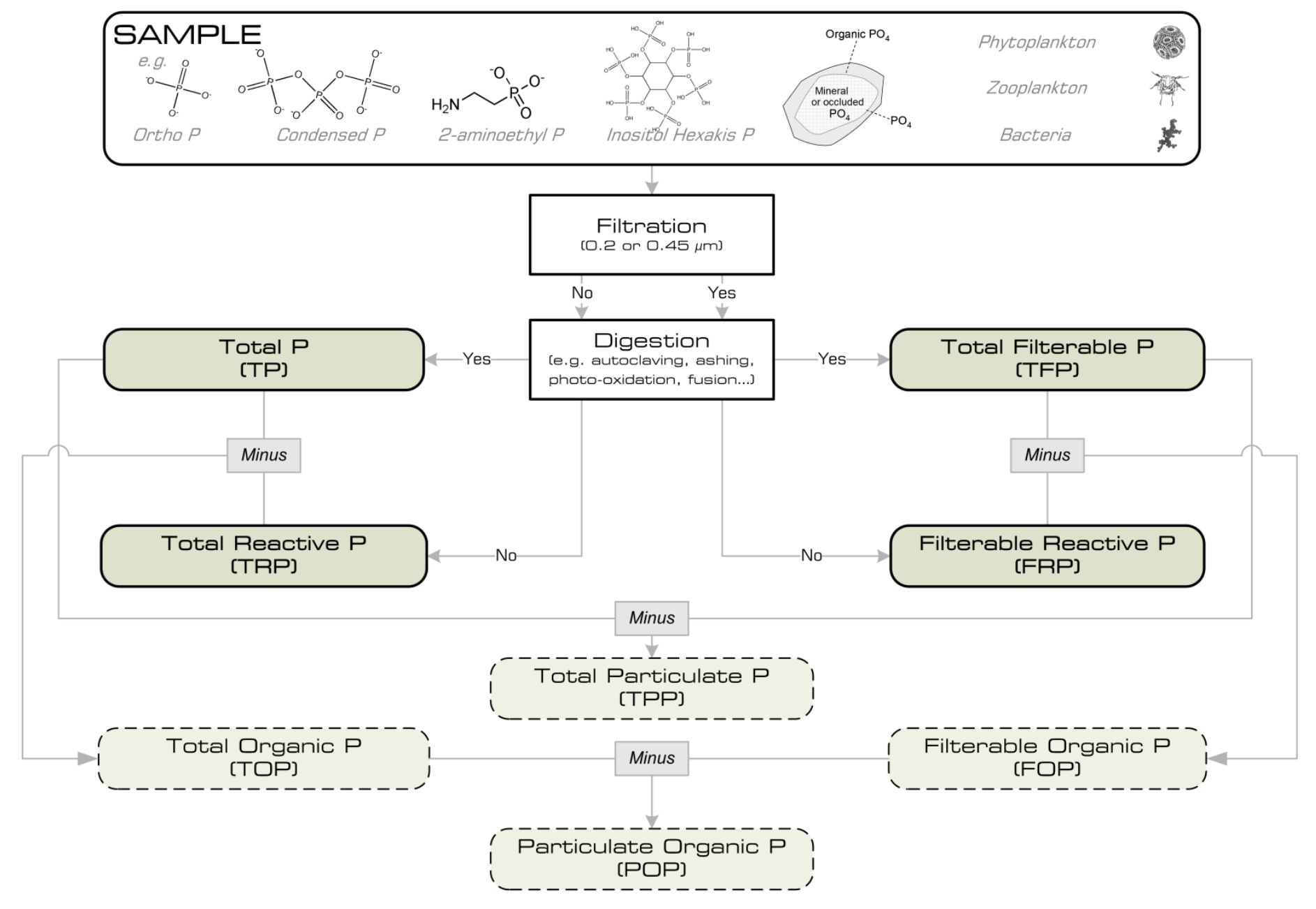

$\bigcirc$ Fraction measured by spectrophotometry $\left(\begin{array}{c}-- \\ -\end{array}\right)$ Fraction usually deduced by substraction 
Fig. 3 (a) Schematic diagram of a compact, portable FI analyser for the determination of phosphate. PP, peristaltic pump; TFF, $0.2 \mathrm{~mm}$ tangential flow filter; FS, differential flow splitter; PG, propellant gas and regulator; MC, mixing coil; FC, flow cell; V0, 2-way valve; V1, V2 and V3, miniature solenoid valves; R1, ammonium molybdate reagent; $R 2$, tin(II) chloride reagent; Std, standard. (b) Phosphate concentrations obtained underway in Port Phillip Bay using the portable FIA system compared with those obtained for samples collected by hand and analysed in the laboratory. Adapted, with permission, from A.J. Lyddy-Meaney, P.S. Ellis, P.J. Worsfold, E.C.V. Butler and I. D. McKelvie, A compact flow injection analysis system for surface mapping of phosphate in marine waters, Talanta, 58 (2002) 1043-1053.

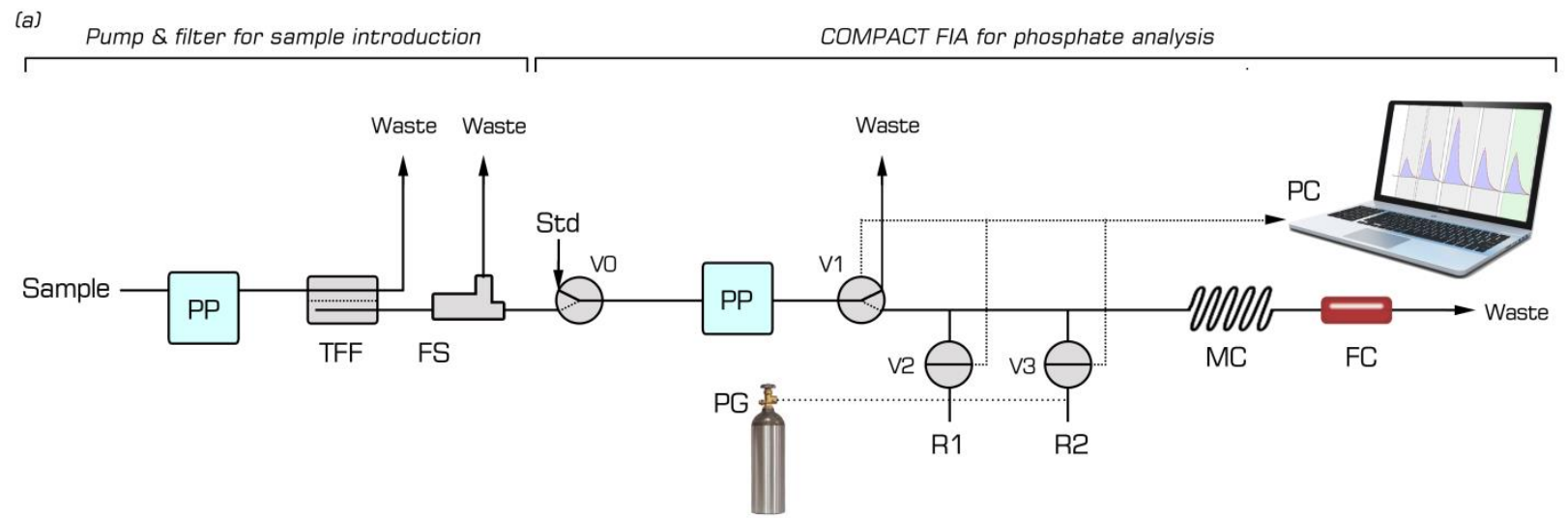

(b)

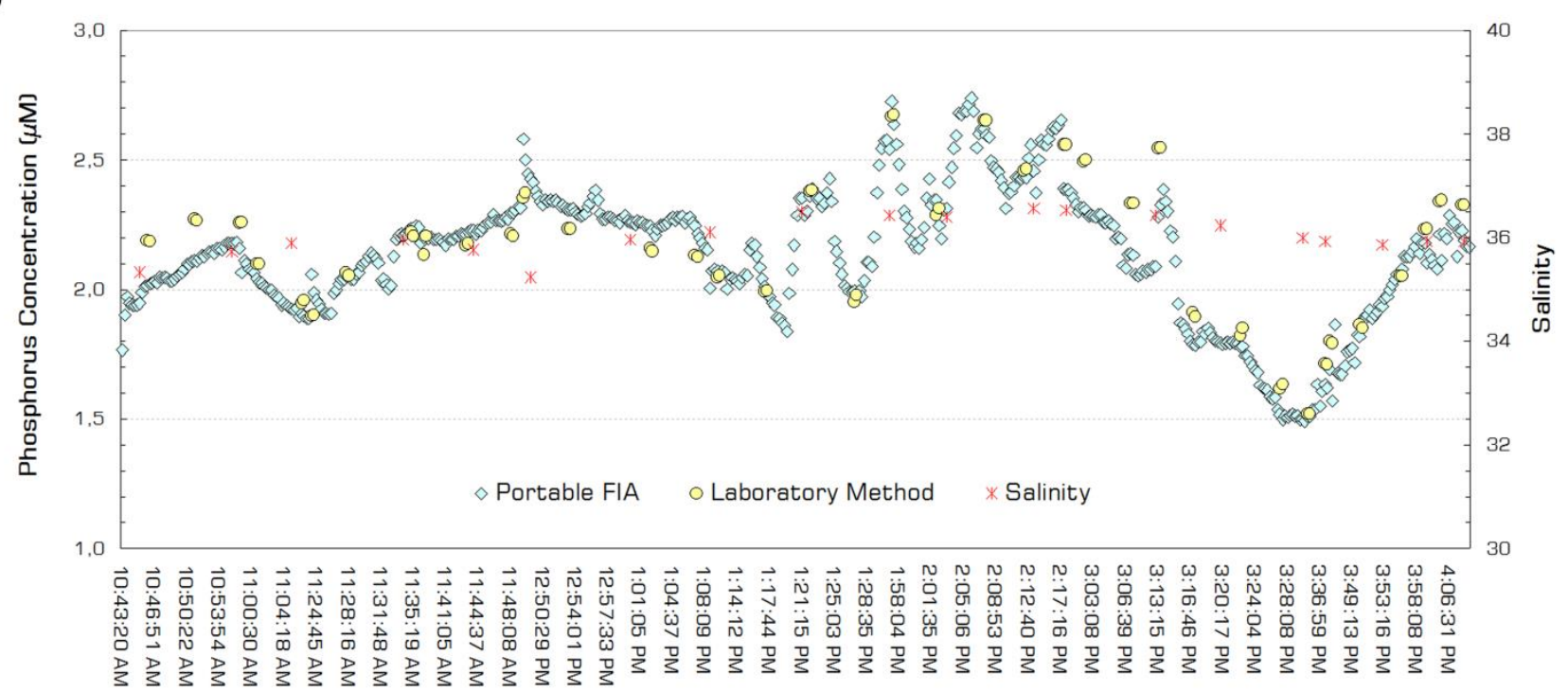

Time [min] 
Fig. 4. FI manifold incorporating a liquid core waveguide (LWCC) for the determination of molybdate reactive phosphorus (top). Typical detector trace and calibration using standards in the range 0.01 to $1 \mu \mathrm{M} \mathrm{PO} \mathrm{PO}_{4} \mathrm{P}$ obtained using a LWCC of $1 \mathrm{~m}$ path length. Error bars \pm 3 standard deviations, $n=3$ (bottom). Reproduced, with permission, from L.J. Gimbert, P.M. Haygarth, P.J. Worsfold, Determination of nanomolar concentrations of phosphate in natural waters using flow injection with a long path length liquid waveguide capillary cell and solid-state spectrophotometric detection, Talanta, 71 (2007) 1624-1628.
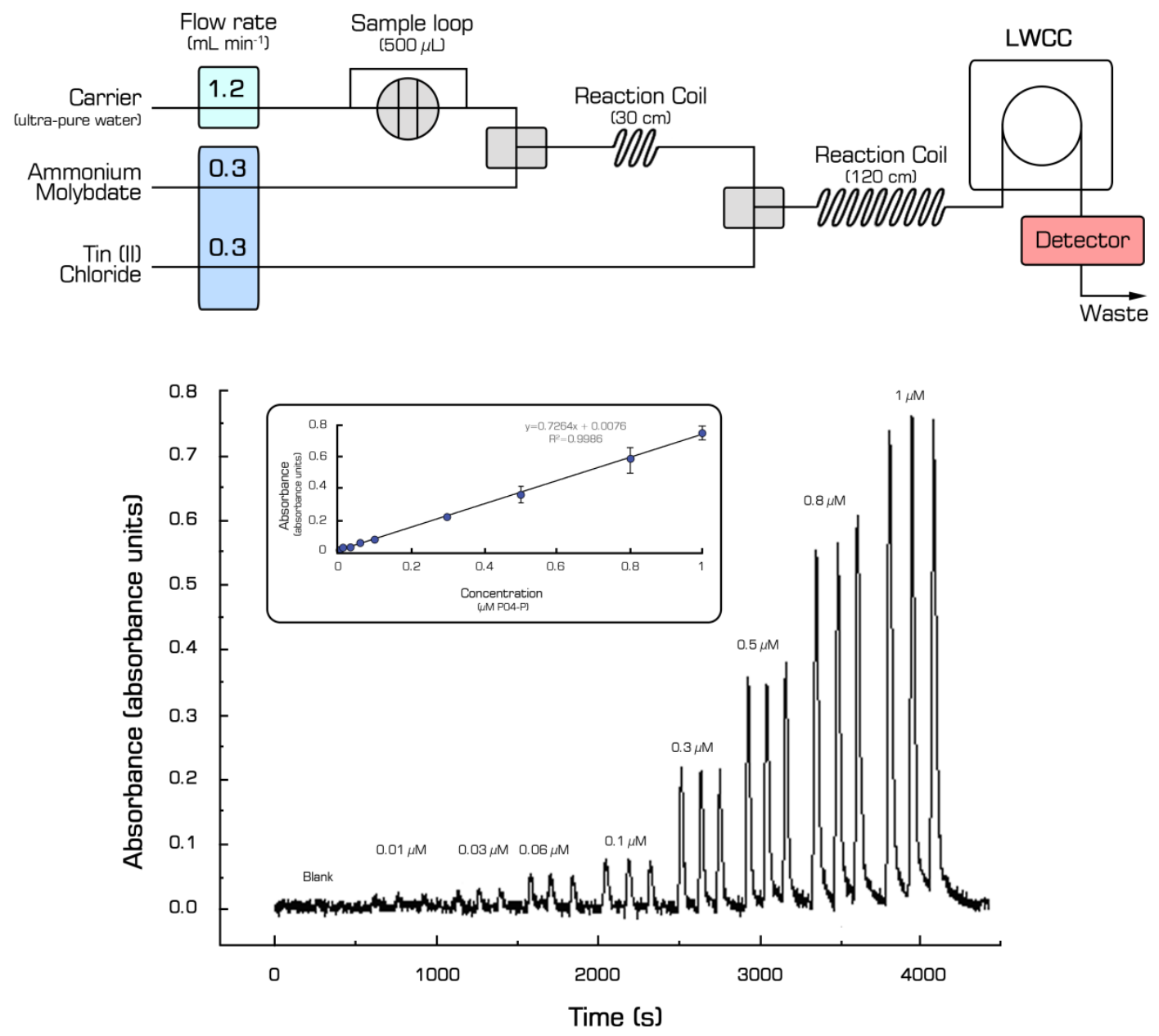
Fig. 5. Schematic of the experimental design for the speciation of dissolved organic phosphorus in natural waters. The left-hand side shows the assay preparation (with/without enzyme), incubation and surfactant addition. The centre describes the flow injection manifold used for DRP measurement. The right-hand side shows an example of triplicate peaks obtained with and without enzyme added. The difference represents the fraction of enzymatically hydrolysable P (EHP). Adapted, with permission, from P. Monbet, I.D. McKelvie , A. Saefumillah and P.J. Worsfold, A protocol to assess the enzymatic release of dissolved organic phosphorus species in waters under environmentally relevant conditions, Environmental Science and Technology, 41 (2007) 7479-7485. Copyright 2007, American Chemical Society.

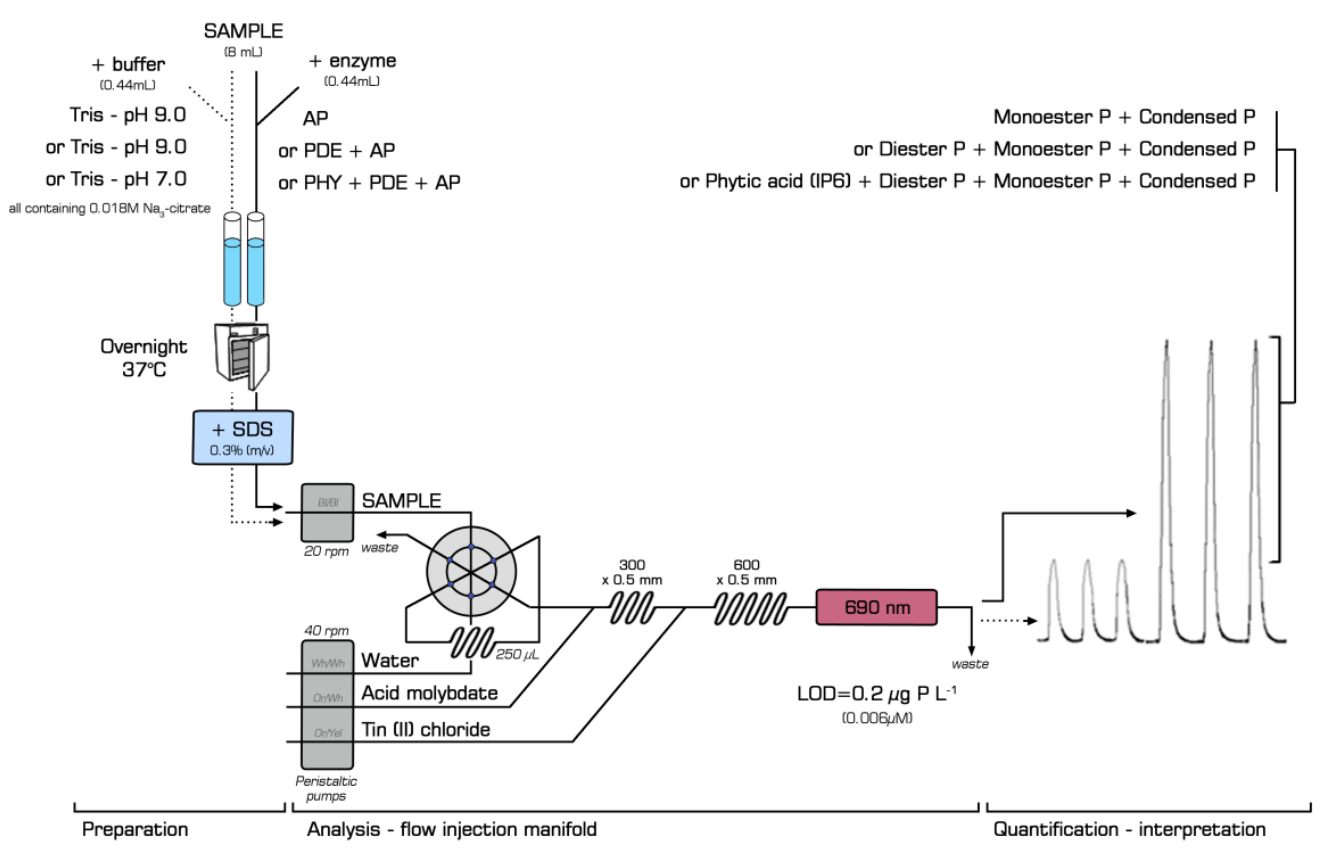


[1] R.E. Hecky, P. Kilham, Nutrient limitation of phytoplankton in freshwater and marine environments: a review of recent evidences of the effects of enrichment, Limnology and Oceanography, 33 (1988) 796822.

[2] J.J. Elser, Phosphorus: A limiting nutrient for humanity?, Current Opinion in Biotechnology, 23 (2012) 833-838.

[3] G. Maier, R.J. Nimmo-Smith, G.A. Glegg, A.D. Tappin, P.J. Worsfold, Estuarine eutrophication in the UK: Current incidence and future trends, Aquatic Conservation: Marine and Freshwater Ecosystems, 19 (2009) 43-56.

[4] P.M. Vitousek, S. Porder, B.Z. Houlton, O.A. Chadwick, Terrestrial phosphorus limitation: mechanisms, implications, and nitrogen-phosphorus interactions, Ecological Applications, 20 (2010) 515.

[5] K.C. Ruttenberg, The Global Phosphorus Cycle, Treatise on Geochemistry: Second Edition, Elsevier, 2013, pp. 499-558.

[6] U. Brunner, R. Bachofen, The biogeochemical cycles of phosphorus: A review of local and global consequences of the atmospheric input, Toxicological and Environmental Chemistry, 67 (1998) 171-188.

[7] L. Reijnders, Phosphorus resources, their depletion and conservation, a review, Resources, Conservation and Recycling, 93 (2014) 32-49.

[8] P.M. Haygarth, H.P. Jarvie, S.M. Powers, A.N. Sharpley, J.J. Elser, J. Shen, H.M. Peterson, N.I. Chan, N.J. Howden, T. Burt, F. Worrall, F. Zhang, X. Liu, Sustainable phosphorus management and the need for a long-term perspective: the legacy hypothesis, Environmental science \& technology, 48 (2014) 8417-8419.

[9] P.J.A. Withers, C. Neal, H.P. Jarvie, D.G. Doody, Agriculture and eutrophication: Where do we go from here?, Sustainability (Switzerland), 6 (2014) 5853-5875.

[10] K. Ashley, D. Cordell, D. Mavinic, A brief history of phosphorus: From the philosopher's stone to nutrient recovery and reuse, Chemosphere, 84 (2011) 737-746.

[11] M.J. Bowes, J.T. Smith, H.P. Jarvie, C. Neal, R. Barden, Changes in point and diffuse source phosphorus inputs to the River Frome (Dorset, UK) from 1966 to 2006, Science of the Total Environment, 407 (2009) 1954-1966.

[12] N.A. Serediak, E.E. Prepas, G.J. Putz, Eutrophication of freshwater systems, Treatise on Geochemistry: Second edition, Elsevier, 2013, pp. 305-323.

[13] P. Monbet, I.D. McKelvie, P.J. Worsfold, Dissolved organic phosphorus speciation in the waters of the Tamar estuary (SW England), Geochim. Cosmochim. Acta, 73 (2009) 1027-1038.

[14] S.A. Sanudo-Wilhemy, A phosphate alternative, Nature, 439 (2006) 25-26.

[15] L.J. Gimbert, P.J. Worsfold, P.M. Haygarth, Processes affecting transfer of sediment and colloids, with associated phosphorus, from intensively farmed grasslands: Colloid and sediment characterization methods, Hydrological Processes, 21 (2007) 275-279.

[16] J. Buffle, G.G. Leppard, Characterization of aquatic colloids and macromolecules. 2. Key role of physical structures on analytical results, Environ. Sci. Technol., 29 (1995) 2176-2184.

[17] J. Buffle, G.G. Leppard, Characterization of aquatic colloids and macromolecules. 1. Structure and behavior of colloidal material, Environ. Sci. Technol., 29 (1995) 2169-2175.

[18] R. Kretzschmar, M. Borkovec, D. Grolimund, M. Elimelech, Mobile Subsurface Colloids and Their Role in Contaminant Transport, Advances in Agronomy, 66 (1999) 121-193.

[19] A.J. Horowitz, A review of selected inorganic surface water quality-monitoring practices: Are we really measuring what we think, and if so, are we doing it right?, Environ. Sci. Technol., 47 (2013) 24712486.

[20] A.J. Wade, E.J. Palmer-Felgate, S.J. Halliday, R.A. Skeffington, M. Loewenthal, H.P. Jarvie, M.J. Bowes, G.M. Greenway, S.J. Haswell, I.M. Bell, E. Joly, A. Fallatah, C. Neal, R.J. Williams, E. Gozzard, J.R. Newman, Hydrochemical processes in lowland rivers: Insights from in situ, high-resolution monitoring, Hydrology and Earth System Sciences, 16 (2012) 4323-4342.

[21] I.G. Littlewood, C.D. Watts, J.M. Custance, Systematic application of United Kingdom river flow and quality databases for estimating annual river mass loads (1975-1994), Science of The Total Environment, 210-211 (1998) 21-40. 
[22] C. Stamm, H.P. Jarvie, T. Scott, What's more important for managing phosphorus: Loads, concentrations or both?, Environ. Sci. Technol., 48 (2014) 23-24.

[23] H.P. Jarvie, C. Neal, P.J.A. Withers, D.B. Baker, R.P. Richards, A.N. Sharpley, Quantifying phosphorus retention and release in rivers and watersheds using extended End-Member Mixing Analysis (E-EMMA) J. Environ. Qual., 40 (2011) 492-504.

[24] P.J.A. Withers, H.P. Jarvie, Delivery and cycling of phosphorus in rivers: A review, Science of the Total Environment, 400 (2008) 379-395.

[25] M. Zamparas, I. Zacharias, Restoration of eutrophic freshwater by managing internal nutrient loads. A review, Science of the Total Environment, 496 (2014) 551-562.

[26] J.G. Ferreira, J.H. Andersen, A. Borja, S.B. Bricker, J. Camp, M. Cardoso da Silva, E. Garcés, A.S. Heiskanen, C. Humborg, L. Ignatiades, C. Lancelot, A. Menesguen, P. Tett, N. Hoepffner, U. Claussen, Overview of eutrophication indicators to assess environmental status within the European Marine Strategy Framework Directive, Estuarine, Coastal and Shelf Science, 93 (2011) 117-131.

[27] I.G. Littlewood, T.J. Marsh, Annual freshwater river mass loads from Great Britain, 1975-1994: estimation algorithm, database and monitoring network issues, Journal of Hydrology, 304 (2005) 221237.

[28] J.C. Rozemeijer, J. Klein, H.P. Broers, T.P. van Tol-Leenders, B. van der Grift, Water quality status and trends in agriculture-dominated headwaters; a national monitoring network for assessing the effectiveness of national and European manure legislation in The Netherlands, Environ. Monit. Assess., 186 (2014) 8981-8995.

[29] A.D. Tappin, U. Mankasingh, I.D. McKelvie, P.J. Worsfold, Temporal variability in nutrient concentrations and loads in the River Tamar and its catchment (SW England) between 1974 and 2004, Environ. Monit. Assess., 185 (2013) 4791-4818.

[30] S.D.W. Comber, R. Smith, P. Daldorph, M.J. Gardner, C. Constantino, B. Ellor, Development of a chemical source apportionment decision support framework for catchment management, Environ. Sci. Technol., 47 (2013) 9824-9832.

[31] Directive 2000/60/EC of the European Parliament and of the Council of 23 October 2000 establishing a framework for Community action in the field of water policy, Official Journal of the European Communities, 43 (2000) L327/321.

[32] Directive 2008/56/EC of the European Parliament and of the Council of 17 June 2008 establishing a framework for community action in the field of marine environmental policy (Marine Strategy Framework Directive), Official Journal of the European Union, 51 (2008) L164/119.

[33] UKTAG, UK Environmental standards and conditions (phase 1), 2008.

[34] UKTAG, Phophorus standards in rivers. Updated Recommendations., 2013, pp. 13.

[35] H.P. Jarvie, J.A. Withers, C. Neal, Review of robust measurement of phosphorus in river water: Sampling, storage, fractionation and sensitivity, Hydrology and Earth System Sciences, 6 (2002) 113132.

[36] G. Hanrahan, P. Gardolinski, M. Gledhill, P. Worsfold, Environmental Monitoring of Nutrients, in: F.R. Burden, I.D. McKelvie, U. Förstner, A. Guenther (Eds.) Environmental Monitoring Handbook, McGraw-Hill, New York, 2002, pp. 8.1-8.16.

[37] P.M. Burke, S. Hill, N. Iricanin, C. Douglas, P. Essex, D. Tharin, Evaluation of preservation methods for nutrient species collected by automatic samplers, Environ. Monit. Assess., 80 (2002) 149-173.

[38] A.R. Kotlash, B.C. Chessman, Effects of water sample preservation and storage on nitrogen and phosphorus determinations: Implications for the use of automated sampling equipment, Water Research, 32 (1998) 3731-3737.

[39] I. Donohue, K. Irvine, Quantifying variability within water samples: The need for adequate subsampling, Water Research, 42 (2008) 476-482.

[40] M.J. Bowes, H.P. Jarvie, S.J. Halliday, R.A. Skeffington, A.J. Wade, M. Loewenthal, E. Gozzard, J.R. Newman, E.J. Palmer-Felgate, Characterising phosphorus and nitrate inputs to a rural river using high-frequency concentration-flow relationships, Science of the Total Environment, 511 (2015) 608-620.

[41] P.C.F.C. Gardolinski, P.J. Worsfold, I.D. McKelvie, Seawater induced release and transformation of organic and inorganic phosphorus from river sediments, Water Research, 38 (2004) 688-692.

[42] P.C.F.C. Gardolinski, G. Hanrahan, E.P. Achterberg, M. Gledhill, A.D. Tappin, W.A. House, P.J. Worsfold, Comparison of sample storage protocols for the determination of nutrients in natural waters, Water Research, 35 (2001) 3670-3678.

[43] P.M. Haygarth, C.D. Ashby, S.C. Jarvis, Short-term changes in the molybdate reactive phosphorus of stored soil waters, J. Environ. Qual., 24 (1995) 1133-1140. 
[44] W. Maher, L. Woo, Procedures for the storage and digestion of natural waters for the determination of filterable reactive phosphorus, total filterable phosphorus and total phosphorus, Anal. Chim. Acta, 375 (1998) 5-47.

[45] G.E.M. Hall, G.F. Bonham-Carter, A.J. Horowitz, K. Lum, C. Lemieux, B. Quemerais, J.R. Garbarino, The effect of using different $0.45 \mu \mathrm{m}$ filter membranes on 'dissolved' element concentrations in natural waters, Applied Geochemistry, 11 (1996) 243-249.

[46] A.J. Horowitz, K.A. Elrick, M.R. Colberg, The effect of membrane filtration artifacts on dissolved trace element concentrations, Water Research, 26 (1992) 753-763.

[47] P.J. Worsfold, L.J. Gimbert, U. Mankasingh, O.N. Omaka, G. Hanrahan, P.C.F.C. Gardolinski, P.M. Haygarth, B.L. Turner, M.J. Keith-Roach, I.D. McKelvie, Sampling, sample treatment and quality assurance issues for the determination of phosphorus species in natural waters and soils, Talanta, 66 (2005) 273-293.

[48] W.A. House, H. Casey, L. Donaldson, S. Smith, Factors affecting the coprecipitation of inorganic phosphate with calcite in hardwaters-I Laboratory studies, Water Research, 20 (1986) 917-922.

[49] W.A. House, H. Casey, S. Smith, Factors affecting the coprecipitation of inorganic phosphate with calcite in hardwaters-II Recirculating experimental stream system, Water Research, 20 (1986) 923-927.

[50] E.A. Nagul, S.D. Kolev, I.D. McKelvie, P.J. Worsfold, The molybdenum blue reaction for the determination of orthophosphate revisited: Opening the black box, Anal. Chim. Acta, 890 (2015

) 60-82.

[51] W. Maher, F. Krikowa, D. Wruck, H. Louie, T. Nguyen, W.Y. Huang, Determination of total phosphorus and nitrogen in turbid waters by oxidation with alkaline potassium peroxodisulfate and low pressure microwave digestion, autoclave heating or the use of closed vessels in a hot water bath: Comparison with Kjeldahl digestion, Anal. Chim. Acta, 463 (2002) 283-293.

[52] D.H. Menzel, N. Corwin, The measurement of total phosphorus in seawater based on the liberation of organically bound fractions by persulphate oxidation, Limnology and Oceanography, 10 (1965) 280282.

[53] D.S. Jeffries, F.P. Dieken, D.E. Jones, Performance of the autoclave digestion method for total phosphorus analysis, Water Research, 13 (1979) 275-279.

[54] L. Woo, W. Maher, Determination of phosphorus in turbid waters using alkaline potassium peroxodisulphate digestion, Anal. Chim. Acta, 315 (1995) 123-135.

[55] J.J. Ridal, R.M. Moore, A re-examination of the measurement of dissolved organic phosphorus in seawater, Marine Chemistry, 29 (1990) 19-31.

[56] M.E. Gales Jr., E.C. Julian, R.C. Kroner, Method for quantitative determination of total phosphorus in water, American Water Works Association Journal, 58 (1966) 1363-1368.

[57] S.J. Eisenreich, R.T. Bannerman, D.E. Armstrong, A simplified phosphorus analysis technique, Environmental Letters, 9 (1975) 43-53.

[58] P.M. Haygarth, M.S. Warwick, W.A. House, Size distribution of colloidal molybdate reactive phosphorus in river waters and soil solution, Water Research, 31 (1997) 439-448.

[59] A. Aminot, R. Kérouel, An automated photo-oxidation method for the determination of dissolved organic phosphorus in marine and fresh water, Marine Chemistry, 76 (2001) 113-126.

[60] J. Golimowski, K. Golimowska, UV-photooxidation as pretreatment step in inorganic analysis of environmental samples, Anal. Chim. Acta, 325 (1996) 111-133.

[61] R.L. Benson, I.D. McKelvie, B.T. Hart, Y.B. Truong, I.C. Hamilton, Determination of total phosphorus in waters and wastewaters by on-line UV/thermal induced digestion and flow injection analysis, Anal. Chim. Acta, 326 (1996) 29-39.

[62] I.D. McKelvie, B.T. Hart, T.J. Cardwell, R.W. Cattrall, Spectrophotometric determination of dissolved organic phosphorus in natural waters using in-line photo-oxidation and flow injection, Analyst, 114 (1989) 1459-1463.

[63] R.L. Benson, I.D. McKelvie, B.T. Hart, I.C. Hamilton, Determination of total phosphorus in waters and wastewaters by on-line microwave-induced digestion and flow-injection analysis, Anal. Chim. Acta, 291 (1994) 233-242.

[64] W. Maher, S. Forster, F. Krikowa, P. Snitch, G. Chapple, P. Craig, Measurement of trace elements and phosphorus in marine animal and plant tissues by low-volume microwave digestion and ICP-MS, Atomic Spectroscopy, 22 (2001) 361-370.

[65] I.D. McKelvie, D.M. Peat, P.J. Worsfold, Techniques for the quantification and speciation of phosphorus in natural waters, Analytical proceedings including Analytical Communications, 32 (1995) 437-445. 
[66] M. Maruo, M. Ishimaru, Y. Azumi, Y. Kawasumi, O. Nagafuchi, H. Obata, Comparison of soluble reactive phosphorus and orthophosphate concentrations in river waters, Limnology, 17 (2016) 7-12.

[67] M. Hens, R. Merckx, The role of colloidal particles in the speciation and analysis of "dissolved" phosphorus, Water Research, 36 (2002) 1483-1492.

[68] P.G.W. Jones, C.P. Spencer, Comparison of several methods of determining inorganic phosphate in sea water, Journal of the Marine Biological Association of the United Kingdom, 43 (1963) 251-273.

[69] J. Murphy, J.P. Riley, A modified single solution method for the determination of phosphate in natural waters, Anal. Chim. Acta, 27 (1962) 31-36.

[70] J.E. Going, S.J. Eisenreich, Spectrophotometric studies of reduced molybdoantimonylphosphoric acid, Anal. Chim. Acta, 70 (1974) 95-106.

[71] L. Drummond, W. Maher, Determination of phosphorus in aqueous solution via formation of the phosphoantimonylmolybdenum blue complex. Re-examination of optimum conditions for the analysis of phosphate, Anal. Chim. Acta, 302 (1995) 69-74.

[72] P.J. Worsfold, J.R. Clinch, H. Casey, Spectrophotometric Field Monitor for Water Quality Parameters. The Determination of Phosphate, Anal. Chim. Acta, 197 (1987) 43-50.

[73] W. Frenzel, I.D. McKelvie, Photometry, in: S.D. Kolev, I.D. McKelvie (Eds.) Advances in flow injection analysis and related techniques, Elsevier, Amsterdam, 2008, pp. 311-342.

[74] A.J. Lyddy-Meaney, P.S. Ellis, P.J. Worsfold, E.C.V. Butler, I.D. McKelvie, A compact flow injection analysis system for surface mapping of phosphate in marine waters, Talanta, 58 (2002) 1043-1053.

[75] E.A. Nagul, I.D. McKelvie, S.D. Kolev, The nature of the salt error in the Sn(II)-reduced molybdenum blue reaction for determination of dissolved reactive phosphorus in saline waters, Anal. Chim. Acta, 896 (2015) 120-127.

[76] E.A. Nagul, I.D. McKelvie, S.D. Kolev, The use of on-line UV photoreduction in the flow analysis determination of dissolved reactive phosphate in natural waters, Talanta, 133 (2015) 155-161.

[77] C. Neal, M. Neal, H. Wickham, Phosphate measurement in natural waters: Two examples of analytical problems associated with silica interference using phosphomolybdic acid methodologies, Science of The Total Environment, 251-252 (2000) 511-522.

[78] P.R. Freeman, I.D. McKelvie, B.T. Hart, T.J. Cardwell, Flow-injection technique for the determination of low levels of phosphorus in natural waters, Anal. Chim. Acta, 234 (1990) 409-416.

[79] O. Broberg, K. Pettersson, Analytical Determination of orthophosphate in water, Hydrobiologia, 170 (1988) 45-59.

[80] M. Grace, Y. Udnan, I. McKelvie, J. Jakmunee, K. Grudpan, On-line removal of sulfide interference in phosphate determination by flow injection analysis, Environmental Chemistry, 3 (2006) 19-25.

[81] K.S. Johnson, R.L. Petty, Determination of Phosphate in Seawater by Flow Injection Analysis with Injection of Reagent, Anal. Chem., 54 (1982) 1185-1187.

[82] P.S. Ellis, A.J. Lyddy-Meaney, P.J. Worsfold, I.D. McKelvie, Multi-reflection photometric flow cell for use in flow injection analysis of estuarine waters, Anal. Chim. Acta, 499 (2003) 81-89.

[83] A.G. Fogg, S.P. Scullion, E. T.E., B.J. Birch, Adaptation of on-line reactions developed for use with flow injection with amperometric detection for use in disposable sensor devices: Reductive determination of phosphate as preformed 12-molybdophosphate in a capillary-fill device, Analyst, 115 (1990) 12771281.

[84] S.M. Harden, W.K. Nonidez, Determination of Orthophosphate by Flow Injection Analysis with Amperometric Detection, Anal. Chem., 56 (1984) 2218-2223.

[85] J.C. Quintana, L. Idrissi, G. Palleschi, P. Albertano, A. Amine, M. El Rhazi, D. Moscone, Investigation of amperometric detection of phosphate: Application in seawater and cyanobacterial biofilm samples, Talanta, 63 (2004) 567-574.

[86] A.V. Kolliopoulos, D.K. Kampouris, C.E. Banks, Rapid and Portable Electrochemical Quantification of Phosphorus, Analytical Chemistry, 87 (2015) 4269-4274.

[87] M. Kishida, T. Aoki, Determination of phosphate utilizing fluorescent reaction of thiamine with molybdovanadophosphate by flow injection analysis, Journal of Flow Injection Analysis, 15 (1998) 234240.

[88] S. Motomizu, M. Oshima, N. Katsumura, Fluorimetric determination of phosphate in sea water by flow injection analysis, Analytical Science and Technology, 8 (1995) 843-848.

[89] C. Frank, F. Schroeder, R. Ebinghaus, W. Ruck, Using sequential injection analysis for fast determination of phosphate in coastal waters, Talanta, 70 (2006) 513-517.

[90] L. Kröckel, H. Lehmann, T. Wieduwilt, M.A. Schmidt, Fluorescence detection for phosphate monitoring using reverse injection analysis, Talanta, 125 (2014) 107-113. 
[91] M. Yaqoob, A. Nabi, P.J. Worsfold, Determination of nanomolar concentrations of phosphate in freshwaters using flow injection with luminol chemiluminescence detection, Anal. Chim. Acta, 510 (2004) 213-218.

[92] APHA-AWWA-WEF, Standard methods for the examination of water and wastewater, 21 st ed., Centennial edition, Washington, 2005.

[93] S. Motomizu, Z.H. Li, Trace and ultratrace analysis methods for the determination of phosphorus by flow-injection techniques, Talanta, 66 (2005) 332-340.

[94] J.D.H. Strickland, T.R. Parsons, A Practical Handbook of Seawater Analysis, Bulletin 167, Second ed., Fisheries Research Board of Canada, Ottawa, 1972.

[95] Y. Liang, D. Yuan, Q. Li, Q. Lin, Flow injection analysis of ultratrace orthophosphate in seawater with solid-phase enrichment and luminol chemiluminescence detection, Anal. Chim. Acta, 571 (2006) 184-190.

[96] S. Motomizu, M. Oshima, Spectrophotometric determination of phosphorus as orthophosphate based on solvent extraction of the ion associate of molybdophosphate with malachite green using flow injection, The Analyst, 112 (1987) 295-300.

[97] E.A. Nagul, C. Fontàs, I.D. McKelvie, R.W. Cattrall, S.D. Kolev, The use of a polymer inclusion membrane for separation and preconcentration of orthophosphate in flow analysis, Anal. Chim. Acta, 803 (2013) 82-90.

[98] Y. Udnan, I.D. McKelvie, M.R. Grace, J. Jakmunee, K. Grudpan, Evaluation of on-line preconcentration and flow-injection amperometry for phosphate determination in fresh and marine waters, Talanta, 66 (2005) 461-466.

[99] D.M. Karl, G. Tien, MAGIC: a sensitive and precise method for measuring dissolved phosphorus in aquatic environments, Limnology and Oceanography, 37 (1992) 105-116.

[100] P. Rimmelin, T. Moutin, Re-examination of the MAGIC method to determine low orthophosphate concentration in seawater, Anal. Chim. Acta, 548 (2005) 174-182.

[101] F.I. Ormaza-González, P.J. Statham, Determination of Dissolved Inorganic Phosphorus in natural Waters at Nanomolar Concentrations using a Long Capillary Cell Detector, Anal. Chim. Acta, 244 (1991) 63-70.

[102] L.J. Gimbert, P.M. Haygarth, P.J. Worsfold, Determination of nanomolar concentrations of phosphate in natural waters using flow injection with a long path length liquid waveguide capillary cell and solid-state spectrophotometric detection, Talanta, 71 (2007) 1624-1628.

[103] J.Z. Zhang, J. Chi, Automated analysis of nanomolar concentrations of phosphate in natural waters with liquid waveguide, Environ. Sci. Technol., 36 (2002) 1048-1053.

[104] Q.P. Li, D.A. Hansell, J.Z. Zhang, Underway monitoring of nanomolar nitrate plus nitrite and phosphate in oligotrophic seawater, Limnology and Oceanography: Methods, 6 (2008) 319-326.

[105] S. Huo, J. Zhang, K.M. Yeager, B. Xi, J. Wang, Z. He, F. Wu, High-resolution profiles of dissolved reactive phosphorus in overlying water and porewater of Lake Taihu, China, Environ. Sci. Pollut. Res., 21 (2014) 12989-12999.

[106] W. Li, L.Y. Lee, L.Y.L. Yung, Y. He, C.N. Ong, Combination of in situ preconcentration and on-site analysis for phosphate monitoring in fresh waters, Anal. Chem., 86 (2014) 7658-7665.

[107] C.W. Mohr, R.D. Vogt, O. Røyset, T. Andersen, N.A. Parekh, An in-depth assessment into simultaneous monitoring of dissolved reactive phosphorus (DRP) and low-molecular-weight organic phosphorus (LMWOP) in aquatic environments using diffusive gradients in thin films (DGT), Environ. Sci. Process. Impacts, 17 (2015) 711-727.

[108] P. Monbet, I.D. McKelvie, P.J. Worsfold, Combined gel probes for the in situ determination of dissolved reactive phosphorus in porewaters and characterization of sediment reactivity, Environ. Sci. Technol., 42 (2008) 5112-5117.

[109] R. Kérouel, A. Aminot, Model compounds for the determination of organic and total phosphorus dissolved in natural waters, Anal. Chim. Acta, 318 (1996) 385-390.

[110] C. Van Moorleghem, L. Six, F. Degryse, E. Smolders, R. Merckx, Effect of organic P forms and P present in inorganic colloids on the determination of dissolved $P$ in environmental samples by the diffusive gradient in thin films technique, ion chromatography, and colorimetry, Anal. Chem., 83 (2011) 5317-5323.

[111] M. Aoyagi, Y. Yasumasa, A. Nishida, Rapid spectrophotometric determination of total phosphorus in industrial wastewaters by flow injection analysis including a capillary digestor, Anal. Chim. Acta, 214 (1988) 229-237. 
[112] S. Hinkamp, G. Schwedt, Determination of total phosphorus in waters with amperometric detection by coupling of flow-injection analysis with continuous microwave oven digestion, Anal. Chim. Acta, 236 (1990) 345-350.

[113] M.I.G.S. Almeida, M.A. Segundo, J.L.F.C. Lima, A.O.S.S. Rangel, Multi-syringe flow injection system with in-line microwave digestion for the determination of phosphorus, Talanta, 64 (2004) 12831289.

[114] D.M.W. Peat, I.D. McKelvie, G.P. Matthews, P.M. Haygarth, P.J. Worsfold, Rapid determination of dissolved organic phosphorus in soil leachates and runoff waters by flow injection analysis with on-line photo-oxidation, Talanta, 45 (1997) 47-55.

[115] T. Pérez-Ruiz, C. Martínez-Lozano, V. Tomás, J. Martín, Flow-injection spectrofluorimetric determination of dissolved inorganic and organic phosphorus in waters using on-line photo-oxidation, Anal. Chim. Acta, 442 (2001) 147-153.

[116] O. Tue-Ngeun, P. Ellis, I.D. McKelvie, P. Worsfold, J. Jakmunee, K. Grudpan, Determination of dissolved reactive phosphorus (DRP) and dissolved organic phosphorus (DOP) in natural waters by the use of rapid sequenced reagent injection flow analysis, Talanta, 66 (2005) 453-460.

[117] B.S. Gentle, P.S. Ellis, P.A. Faber, M.R. Grace, I.D. McKelvie, A compact portable flow analysis system for the rapid determination of total phosphorus in estuarine and marine waters, Anal. Chim. Acta, 674 (2010) 117-122.

[118] D.S. Baldwin, Reactive 'organic' phosphorus revisited, Water Research, 32 (1998) 2265-2270.

[119] B.J. Cade-Menun, Using 31P Nuclear Magnetic Resonance to characterize organic phosphorus in envirnmental samples, in: B.L. Turner, E. Frossard, D.S. Baldwin (Eds.), Cabi Publishing, 2005, pp. 2144.

[120] D.M. Karl, K.M. Bjorkman, Phosphorus cycle in seawater: dissolved and particulate pool inventories and selected phosphorus fluxes, Methods in Microbiology 30 (2001) 239-270.

[121] R.A. Berner, J.L. Rao, Phosphorus in sediments of the Amazon River and estuary: Implications for the global flux of phosphorus to the sea, Geochim. Cosmochim. Acta, 58 (1994) 2333-2339.

[122] J.B. Cotner, R.G. Wetzel, Uptake of dissolved inorganic and organic phosphorus compounds by phytoplankton and bacterioplankton, Limnology and Oceanography, 37 (1992) 232-243.

[123] S.T. Dyhrman, P.D. Chappell, S.T. Haley, J.W. Moffett, E.D. Orchard, J.B. Waterbury, E.A. Webb, Phosphonate utilization by the globally important marine diazotroph Triscodesmium, Nature, 439 (2006) 68-71.

[124] S.J. Eisenreich, J.E. Going, Extraction of reduced molybdophosphoric and molybdoantimonylphosphoric acids with oxygenated solvents, Anal. Chim. Acta, 71 (1974) 393-403.

[125] M. Espinosa, B.L. Turner, P.M. Haygarth, Preconcentration and separation of trace phosphorus compounds in soil leachate, J. Environ. Qual., 28 (1999) 1497-1504.

[126] D.Z. Halemejko, R. Chrost, The role of phosphatases in phosphorus mineralization during decomposition of lake phytoplankton blooms, Archiv. fur Hydrobiologie, 101 (1984) 489-502.

[127] H. Quiquampoix, D. Mousain, Enzymatic hydrolysis of organic phosphorus, in: B.L. Turner, E. Frossard, D.S. Baldwin (Eds.) Organic phosphorus in the environment, Cabi Publishing, 2005.

[128] P.J. Worsfold, P. Monbet, A.D. Tappin, M.F. Fitzsimons, D.A. Stiles, I.D. McKelvie, Characterisation and quantification of organic phosphorus and organic nitrogen components in aquatic systems: A Review, Anal. Chim. Acta, 624 (2008) 37-58.

[129] K. Robards, I.D. McKelvie, R.L. Benson, P.J. Worsfold, N.J. Blundell, H. Casey, Determination of carbon, phosphorus, nitrogen and silicon species in waters, Anal. Chim. Acta, 287 (1994) 147-190.

[130] J.D. Strickland, L. Solorzano, Determination of monoesterase hydrolysable phosphate and phosphomonoesterase activity in sea water, in: $\mathrm{H}$. Barnes (Ed.) Some contemporary studies in Marine Science, Allen \& Unwin, London, 1966, pp. 665-675.

[131] S.E. Herbes, H.E. Allen, K.H. Mancy, Enzymatic characterization of soluble organic phosphorus in lake water, Science, 187 (1975) 432-434.

[132] B.L. Turner, I.D. McKelvie, P.M. Haygarth, Characterisation of water-extractable soil organic phosphorus by phosphatase hydrolysis, Soil Biology \& Biochemistry, 34 (2002) 27-35.

[133] P. Monbet, I.D. McKelvie, A. Saefumillah, P.J. Worsfold, A protocol to assess the enzymatic release of dissolved organic phosphorus species in waters under environmentally relevant conditions, Environ. Sci. Technol., 41 (2007) 7479-7485.

[134] Y. Shan, I.D. McKelvie, B.T. Hart, Characterization of immobilized Escherichia coli alkaline phosphatase reactors in flow injection analysis, Anal. Chem., 65 (1993) 3053-3060.

[135] N. Amini, I. McKelvie, An enzymatic flow analysis method for the determination of phosphatidylcholine in sediment pore waters and extracts, Talanta, 66 (2005) 445-452. 
[136] I.D. McKelvie, B.T. Hart, T.J. Cardwell, R.W. Cattrall, Use of immobilized 3-phytase and flow injection for the determination of phosphorus species in natural waters, Anal. Chim. Acta, 316 (1995) 277-289.

[137] V. Ruiz-Calero, M.T. Galceran, Ion chromatographic separations of phosphorus species: A review, Talanta, 66 (2005) 376-410.

[138] D. Jolley, W. Maher, P. Cullen, Rapid method for separating and quantifying orthophosphate and polyphosphates: Application to sewage samples, Water Research, 32 (1998) 711-716.

[139] D. Halliwell, J. Coventry, D. Nash, Inorganic monophosphate determination in overland flow from irrigated grazing systems, Int. J. Environ. Anal. Chem., 76 (2000) 77-87.

[140] Z.X. Guo, Q. Cai, Z. Yang, Determination of glyphosate and phosphate in water by ion chromatography - Inductively coupled plasma mass spectrometry detection, J. Chromatogr. A, 1100 (2005) 160-167.

[141] C. Valls-Cantenys, M. Iglesias, J.L. Todolí, V. Salvadó, Speciation of phosphorus oxoacids in natural and waste water samples, J. Chromatogr. A, 1231 (2012) 16-21.

[142] R.A. Barco, D.G. Patil, W. Xu, L. Ke, C.S. Khachikian, G. Hanrahan, T.M. Salmassi, The development of iodide-based methods for batch and on-line determinations of phosphite in aqueous samples, Talanta, 69 (2006) 1292-1299.

[143] Y.M. Niu, Y. Liang, J.Y. Liu, J.F. Liu, Highly sensitive determination of dialkyl phosphinate acids in environmental samples by ion chromatography tandem mass spectrometry, J. Chromatogr. A, 1394 (2015) 26-35.

[144] ISO/IEC, General requirements for the competence of testing and calibration laboratories, International Organization for Standardization/International Electrotechnical Commission, Geneva, 2005.

[145] P.J. Worsfold, R. Clough, M.C. Lohan, P. Monbet, P.S. Ellis, C.R. Quétel, G.H. Floor, I.D. McKelvie, Flow injection analysis as a tool for enhancing oceanographic nutrient measurements-A review, Anal. Chim. Acta, 803 (2013) 15-40.

[146] A. Aminot, R. Kérouel, Reference material for nutrients in seawater: stability of nitrate, nitrite, ammonia and phosphate in autoclaved samples, Mar. Chem., 49 (1995) 221-232.

[147] V. Clancy, S. Willie, Preparation and certification of a reference material for the determination of nutrients in seawater, Anal. Bioanal. Chem., 378 (2004) 1239-1242.

[148] M. Aoyama, H. Ota, M. Kimura, T. Kitao, H. Mitsuda, A. Murata, K. Sato, Current status of homogeneity and stability of the reference materials for nutrients in seawater, Anal. Sci., 28 (2012) 911916.

[149] M. Aoyama, S. Becker, M. Dai, H. Daimon, L.I. Gordon, H. Kasai, R. Kerouel, N. Kress, D. Masten, A. Murata, N. Nagai, H. Ogawa, H. Ota, H. Saito, K. Saito, T. Shimizu, H. Takano, A. Tsuda, K. Yokouchi, A. Youenou, Recent comparability of oceanographic nutrients data: Results of a 2003 intercomparison exercise using reference materials, Anal. Sci., 23 (2007) 1151-1154.

[150] J. Compton, D. Mallinson, C.R. Glenn, G. Filippelli, I.K. Föllm, G. Shields, Y. Zanin, Variations in the global phosphorus cycle, in: C.R. Glenn, L. Prevot-Lucas, J. Lucas (Eds.) Marine Authigenesis: From Global to MicrobialSociety for Sedimentary Geology, 2000, pp. 21-33.

[151] G.M. Filippelli, The global phosphorus cycle, Reviews in Mineralogy and Geochemistry, 2002.

[152] P.N. Froelich, M.L. Bender, N.A. Luedtke, G.R. Heath, T. Devries, The Marine Phosphorus Cycle, Am. J. Sci., 282 (1982) 474-511.

[153] B. Gumbo, Short-cutting the phosphorus cycle in urban ecosystems, Delft University of Technology, 2005, pp. 326.

[154] R.A. Jahnke, 14 The Phosphorus Cycle, International Geophysics, 1992, pp. 301-315.

[155] A. Lerman, F.T. Mackenzie, R.M. Garrels, Modeling of geochemical cycles: Phosphorus as an example, Memoir of the Geological Society of America, 1975, pp. 205-218.

[156] F.T. MacKenzie, L.M. Ver, C. Sabine, M. Lane, A. Lerman, C, N, P, S global biogeochemical cycles and modeling of global change, in: R. Wollast, F.T. MacKenzie, L. Chou (Eds.) Interactions of C, N, P and S cycles and global change, Springer-Verlag, Berlin, 1993, pp. 1-62.

[157] J.E. Richey, The phosphorus cycle, in: B. Bolin, R.B. Cook (Eds.) SCOPE 21 -The Major Biogeochemical Cycles and Their Interactions, John Wiley and Sons Ltd., Chichester, 1983, pp. 51-56.

[158] V. Smil, Phosphorus: Global Transfers in Douglas, I. (Ed.) Causes and consequences of global environmental change, in: T. Munn (Ed.) Encyclopedia of Global Environmental Change John Wiley \& Sons Ltd., Chichester, 2002, pp. 536-542. 